\title{
Application of Blockchain Technology for iLearning Student Assessment
}

\author{
Sudaryono ${ }^{1}$, Qurotul Aini ${ }^{2}$, Ninda Lutfiani $^{3}$, Firman Hanafi* ${ }^{*}{ }^{4}$,Untung Rahardja ${ }^{5}$ \\ ${ }^{1,2,3,5}$ Magister program Informatics Department, Faculty of Science and Technology, Raharja \\ University, Tangerang, Indonesia \\ ${ }^{4}$ Computer System Study Programme, Faculty of Science and Technology, Raharja University, \\ Tangerang, Indonesia \\ e-mail: ${ }^{1}$ sudaryono@ raharja.info,, 2aini@ raharja.info, ${ }^{3}$ ninda@ raharja.info \\ "firman.hanafi@ raharja.info, ${ }^{5}$ untung@ raharja.info
}

\begin{abstract}
Abstrak
Blockchain adalah teknologi inti yang digunakan untuk membuat cryptocurrency, seperti bitcoin. Sebagai salah satu bagian dari revolusi industri keempat sejak penemuan mesin uap, listrik, dan teknologi informasi, teknologi blockchain mulai diterapkan di berbagai bidang seperti keuangan, kehakiman, dan perdagangan. Teknologi blockchain menggunakan teknik desentralisasi, terdistribusi serta transparansi untuk pengamanan datanya. Penelitian ini bertujuan untuk mengetahui implementasi teknologi blockchain pada bidang pendidikan khususnya di bagian keamanan data. Dalam penelitian ini menggunakan dua metode yaitu metode mind mapping dan metode studi literatur. Hasil penelitian ini menunjukan bahwa dengan adanya teknologi blockchain, data yang ada menjadi lebih aman dari serangan baik dari dalam maupun dari luar karena melewati dua tahap pengamanan yaitu enkripsi dan desentralisasi data.
\end{abstract}

Kata kunci - Blockchain untuk Pendidikan, Desentralisasi, iLearning.

\begin{abstract}
Blockchain is the core technology used to create cryptocurrencies, such as Bitcoin. As one part of the fourth industrial revolution since the invention of steam engines, electricity, and information technology, blockchain technology has begun applied in areas such as finance, judiciary, and trade. Blockchain technology uses decentralized, distributed, and transparency techniques for data security. This research aims to determine the implementation of blockchain technology in the field of education, especially in the Data Security section. The study uses two methods, namely the mind mapping method and literature review. The results of this study showed that with the presence of blockchain technology, the data is more secure from attacks from both inside and outside because it passes through two levels of security, namely encryption, and decentralized data.
\end{abstract}

Keywords - Blockchain for Education, Decentralized, iLearning.

Received January $3^{\text {rd }}, 2020$; Revised April 28 ${ }^{\text {th }}, 2020 ;$ Accepted April $29^{\text {th }}, 2020$ 


\section{INTRODUCTION}

Current technological developments have evolved so rapidly, to date, has reached the level of the fourth industrial revolution since the invention of steam engines, electricity, information technology. As one part of the Industrial Revolution, blockchain technology applied in various areas such as finance, judiciary, and trade. Blockchain is a new technology that integrates decentralization, distributed computing, asymmetric encryption, timestamp, consensus algorithm [1]. The blockchain is peer to peer [2], which is distributed and decentralized where the distributed data is already secure into cryptography. According to Indra Gunawan, cryptography is the science and art to maintain the security of messages by encoding data that was previously added with a password to access the data in need of a password to redecrypt the data [3]. While according to Zeyan Zico Deskiva, cryptography is an art in encoding a message by converting the data that initially had a clear meaning into data that is not plain [4].

The presence of blockchain fulfills the essential elements experienced by the transaction actors, namely trust, transparency, and accountability. Trust in the blockchain comes with a blockchain network, clarity on the blockchain comes with a form of bookkeeping/ledger that can be read by both parties, and accountability in the blockchain comes with a kind of approval that forms a smart contract or Chaincode. Currently, the blockchain implementation also exists in the industrial sector (Smart Manufacturing) [5],[6]. Health sector (e-Medical records [7], cloud storage-based personal health data [8], and integrated personal health record data [9] and currently the blockchain in the field of education (electronic student profile) [12] as well as digital certificates[11]. In this era of technological developments, learning media [10] is also experiencing growth, from physical books to electronic books.

iLearning is a modern learning method that integrates a blend of learning, playing, praying, and working [13] that optimizes learning using electronic books. The iLearning system makes it easier for lecturers to deliver their material; the iLearning method of the learning process does not have to be face to face between lecturers and students. Because learning uses the internet through various devices such as smartphones, laptops, PCs, and so on, students can carry out the learning process as a whole and make students interested in learning. Along with the development of technology, iLearning disruptive [14] whereas, technological developments require that the due security system update to the development of technology, the security system has also developed and made the old security system obsolete and lagging if it still uses the old security system. Someone can hack the system quickly and can manipulate data. One can hack the system soon and can manipulate the data. As such, the iLearning method [18] needs to be updated so that its security system is always new, and the data contained in the order remains secure.

IJCCS Vol. 14, No. 2, April 2020 : $209-218$ 


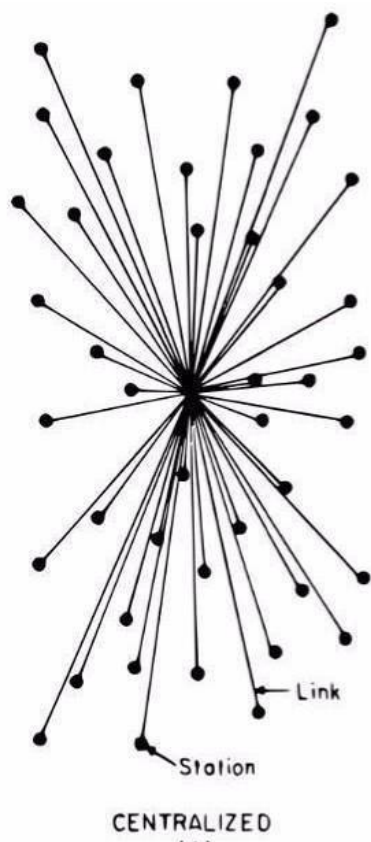

(A)

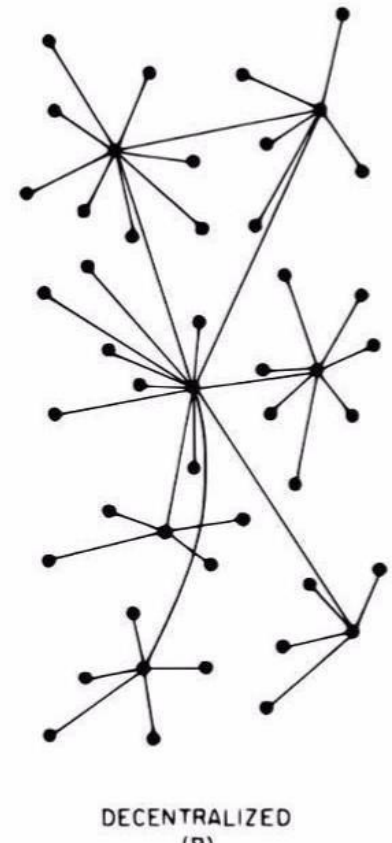

(B)

Figure 1. Data Distribution Method

Source : hackernoon/Data Privacy \& Decentralization

Figure 1 known about how data sharing is dividing into three, namely centralized, decentralized, and distributed. Centralized is a way of sharing data in one direction. Security in the centralized method is not guaranteed because if the center gets impaired. Then the other user will also be affected because all data sources located in one place. Meanwhile, decentralization is a way of sharing a whole data, and all users in it can exchange data without a master who controls data transfer because it can be done independently and is a peer to peer $(\mathrm{P} 2 \mathrm{P})$. The concept is applied in a blockchain so that every data transferred can be secured and not used by irresponsible people.

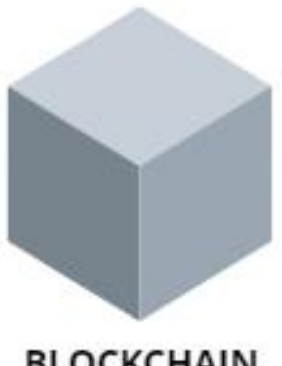

BLOCKCHAIN

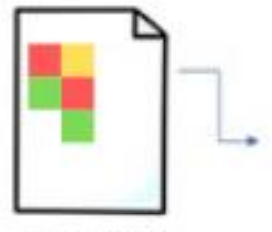

BLOCK 1

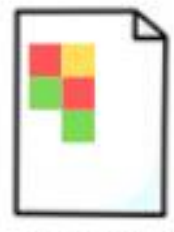

BLOCK 2

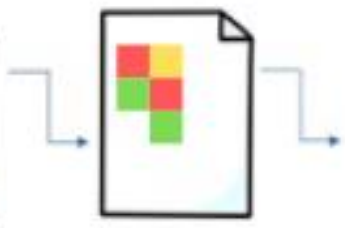

BLOCK 3

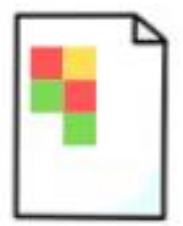

BLOCK 4

Figure 2. Blockchain Book Concept

From figure 2 can be known that in addition to the concepts already mentioned earlier, blockchain also implements a bookkeeping method that is capable of recording all transactions occurring within a ledger. Each existing user, each of which has a large book with the same and accurate data pages, but cannot modify the contents or delete existing data because each data has its private key. So to manipulate the data in the blockchain can be said is impossible because if you want to replace a piece of information should return all existing user records. If one of the data is incomplete or the same, it can be known from a current track record, as each page is interconnected in the blockchain. When a change occurs in the data, the modified page is no longer the same and incomplete as the other page. 


\section{METHODS}

In a research course, using a research method to achieve the goal also gets the accurate and reliable information needed by a researcher to perform several phases in the study. The research method is a stage conducted by researchers who used to answer the purpose of a study. Study literature needed to build a research method. In this paper, to succeed, the authors of this study used two methods of research, namely mind mapping and literature study methods.

\section{Mind Mapping Method}

Mind mapping method is a method that can help students' activities in learning because the advantage of this method is not only to teach students in theory but also to use practical purposes in the learning process. So that students will be able to memorize and understand it [16]. In this study, mind mapping used as the concept of the process of blockchain use.

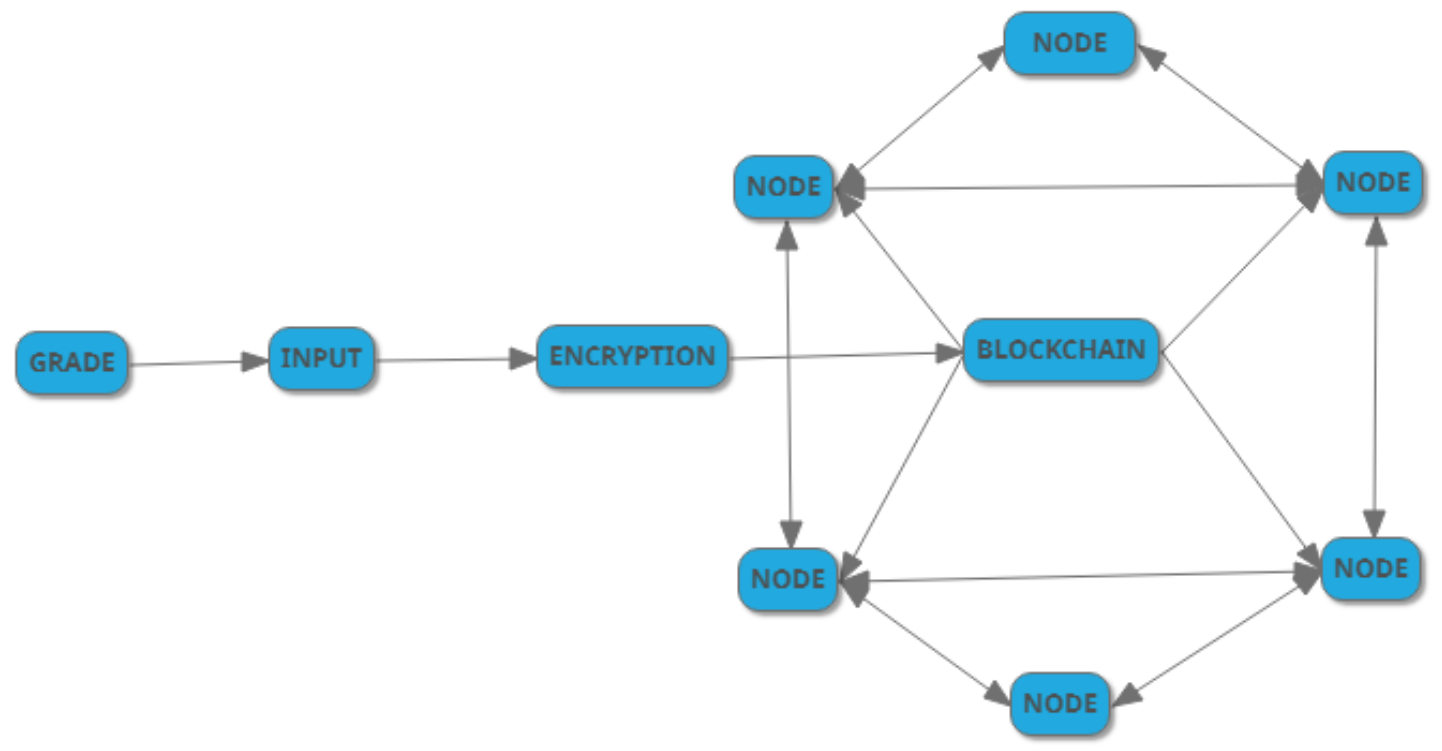

Figures 3. Mind Mapping Blockchain

From figure 3, it can show that storing data in the blockchain is safer than in the cloud because before plugging into the blockchain, data will bypass the encryption process first to transform into a random code. Once encrypted, the code will share into nodes within the blockchain. Nodes in the blockchain are connected to communicate, so the data owned by each node will be the same, and there is nothing different because each node gets an identical copy of the data and fits each other. Therefore, the data that is in the blockchain cannot manipulate.

\section{Literature Review}

The method of a literature review is a method done by finding references, data, and information from books, scientific journals, literature, and opinions of experts who share the topic of research to facilitate writers to Search for a variety of references, data, and information. Several library studies produce previous research on blockchain and other related research. Here are 9 (nine) similar library studies, namely: 
Research conducted by Agus Winarno of the cyber agency and password of the state at the proceedings of the National Seminar of Experts, the year 2019 titled "Desain e-Transkrip Dengan Teknologi Blockchain." This study discusses the application of blockchain technology for e-transcripts. The model has some advantages in autonomy, so recording all data is distributed in a decentralized manner so that each blockchain node has a record of diplomas and transcripts. Decentralized data storage reduces the risk of server down and data loss [17].

Ehsan Nikbakht conducted the research, Manuchehr Shahrokhi, Alford Corriette, in 2019 titled "Blockchain \& Distributed Financial data." This study investigates the emergence of the blockchain to determine eligibility for electronic transfer payments[15].

Research that has been done by Heribertus Yulianton, Rina Candra Noor Santi, Kristophorus Hadiono, and Sri Mulyani from Stikubank University on Sintak in the year 2018 titled "Implementasi Sederhana Blockchain." In this study discussed the simple implementation of blockchain on cryptocurrency to describe the application of blockchain in a simple way [19].

In another study, Pascal Urien from Saclay University in IEEE in 2018 titled "The IoT Blockchain (BIoT): A New Direction for Solving Internet of Things Security and Trust Issues." The study discusses the use of blockchain on the Internet of Things (IoT) for use in sensors to load data [20].

In previous research, Weilin Zheng, Zibin Zheng, Xianping Chen, Kemian Dai, Peishan Li, and Renfei Chen of Sun Yat-sen University at IEEE.org in 2019 titled "NutBaaS: A Blockchain-Asa-Service Platform." This research discusses blockchain as a service platform. Blockchain as the service platform because of its decentralization, persistence, anonymity, and auditing capabilities. In this study, researchers developed a BaaS platform called NutBaaS which provides blockchain services within the cloud computing [21].

Maciel M. Queiroz, Renato Telles, and Silvia H. Bonilla of the University of São Paulo Polytechnic and the Paulista University of Brazil researched the title "Blockchain and integration of supply chain management: A systematic review of the literature. "This study discusses how to identify, analyze, and regulate the writing on blockchains in the context of Supply Chain Management (SCM). The research also explains what major blockchain applications are currently in supply chain management (SCM), what are the disruptions and challenges in supply chain management (SCM) due to blockchain adoption [22].

Research conducted by Muhamed Turkanovic, Marko Holbl, Kristijan Kosic, Marjan Hericko, and Aida Kamisalic from Faculty of Electrical Engineering and Computer Science, the University of Maribor from Faculty of Electrical Engineering and Computer Science, University of Maribor, Slovenia in 2018 entitled "EduCTX: A Blockchain-Based Higher Education Credit Platform." The research discusses the global higher education credit platform proposal, called EduCTX. The Platform based on the concept of the Transfer and accumulation of European credit systems (ECTS). It does a globally decentralized higher education credit [23].

Studies conducted by Artem A. Maksutov, Maxim S. Alexeev, Natalia O. Fedorova, Daniil A. Andreev, in this study, describe the efforts made to detect transactions that can participate in money laundering schemes and possible modification of payment systems based on blockchain technology for AML/CFT purposes [24].

Research conducted by Hafizh Fianto Putra, Wirawan, and Ontoseno Penangsang from Institut Teknologi Sepuluh Nopember (ITS) 2019 entitled "Penerapan Blockchain dan Kriptografi Untuk Keamanan Data pada Jaringan Smart Grid." In this study discussed the security of smart grids existing in smart cities with Blockchain and cryptography because customer data fell to the irresponsible party due to unsafe transmission channels. Using the Blockchain and cryptography on the Smart Grid network will provide additional security for data storage, and cryptography offers confidentiality and authentication on the exchange of data in the system [25].

According to the nine previous studies, the conclusion is that there have been several studies conducted using blockchain technology in various fields. Earlier studies that the use of Blockchain can make the system more secure because every data sent has a private key and is encrypted securely. The synthesis of this research found that in its application, Blockchain has

Application of Blockchain Technology for iLearning Student Assessment (Firman Hanafi) 
not been much in the direction of iLearning Student Assessment. In this research, Blockchain is utilized in the field of education, especially in the security section. Student value data consisting of midterm, final exam, and independent assignment values are input in a system that is already integrated with Blockchain to prevent the modification of data from outside parties. The value that has been input into the system is processed to know the final cost of the student. Once processed, the value will be re-shared via email. All processes that occur are recorded in the Blockchain so that no data is forged because all data held by the user connected.

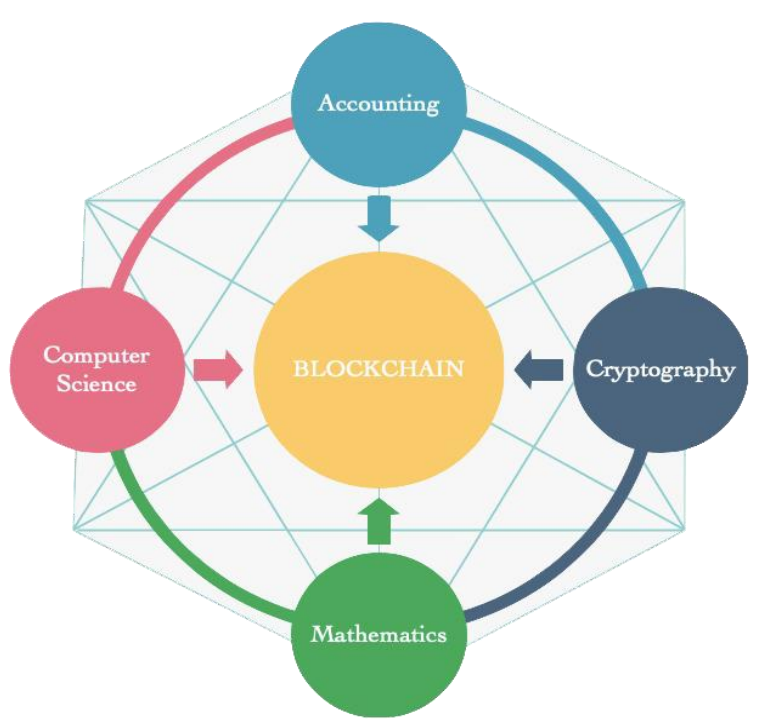

Figure 4. Blockchain Implementation.

From figure 4 about Blockchain implementation, the rapid development of current technology, the Blockchain is not only implemented in cryptocurrency but also applied to mathematics, computer science, and accounting. Cryptocurrency is a virtual digital money system transferred over a secure network [26]. Nowadays, Blockchain is starting to expand into the education sector. With the presence of Blockchain, security systems become more trusted, and values can be stored in the value database securely.

\section{RESULTS AND DISCUSSION}

In the educational world, it is appropriate for the application of Blockchain. By using Blockchain, Education seems to assist in the field of data security. Blockchain can store and convert data into cryptography for safer, and no attacks both internally and externally. Cryptography makes the Blockchain more secure because the changed data will be encrypted into random codes so that others can't open it. The process of calculating the data is concrete and uniquely known as the hash method name. This method works by replacing any existing input into arbitrary and hard-to-understand code so that the encrypted data cannot manipulate. 
RESULT OF MIDTERM EXAM, FINAL EXAM SEMESTER AND INDEPENDENT ASSIGNMENT

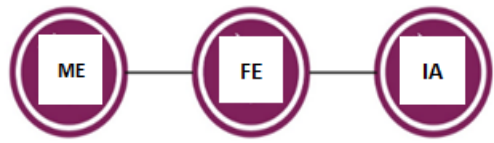

\begin{tabular}{|c|c|c|c|c|c|c|}
\hline No & CLASS CODE & Lessons & SKS & ME & FE & IA \\
\hline 1 & TI402 & Artificial Intelligence & 2 & 80 & 85 & 90 \\
\hline 2 & UM140 & Nationality & 2 & 88 & 85 & 95 \\
\hline 3 & SK201 & Parallel Processing & 3 & 85 & 85 & 85 \\
\hline 4 & MJ200 & Professional Ethics & 2 & 88 & 90 & 88 \\
\hline 5 & SK202 & Interfacing & 3 & 85 & 89 & 95 \\
\hline 6 & TI121 & Assembled Language & 3 & 80 & 85 & 80 \\
\hline 7 & SI131 & Operating System & 3 & 85 & 80 & 87 \\
\hline 8 & MJ201 & Interpersonal Skills & 2 & 85 & 88 & 84 \\
\hline 9 & TI220 & $\begin{array}{c}\text { Human and Computer } \\
\text { Interaction }\end{array}$ & 2 & 88 & 88 & 87 \\
\hline 10 & SK204 & Embedded System & 2 & 80 & 85 & 88 \\
\hline
\end{tabular}

Figure 5. Sample Student Value List

Figure 5 can know the value of these students; three types are mid-semester, final exam, and independent duty. This value is derived from the student's study of one semester to find out how much understanding a student has had in the lesson when one of these values is less or empty. It will affect the graduation of the experience and reduce the student's final value. Then, all these values are converted into one data unit called the last result value data. The higher the ultimate value, the better the grade the benefit gained.

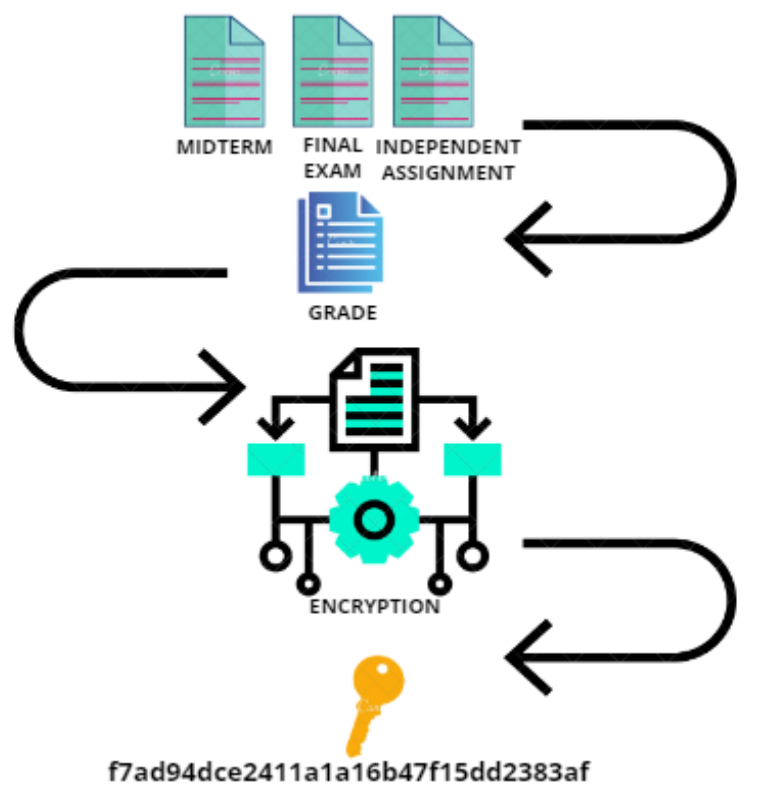

Figure 6. Example of the encryption process

Figure 6 is an example of encryption. So the work of encryption is to convert the data into encryption codes as security to keep the existing data intact and unchanged. Data encryption, the authenticity of a data is maintained even though the information manipulates, because if there is a change in the data, then the encryption code is no longer the same as the previous code. To ensure the authenticity of the data, have to match the encryption code must first be created with the new encryption code. If the system is the same and legitimate, then the data's authenticity can be accountable. 


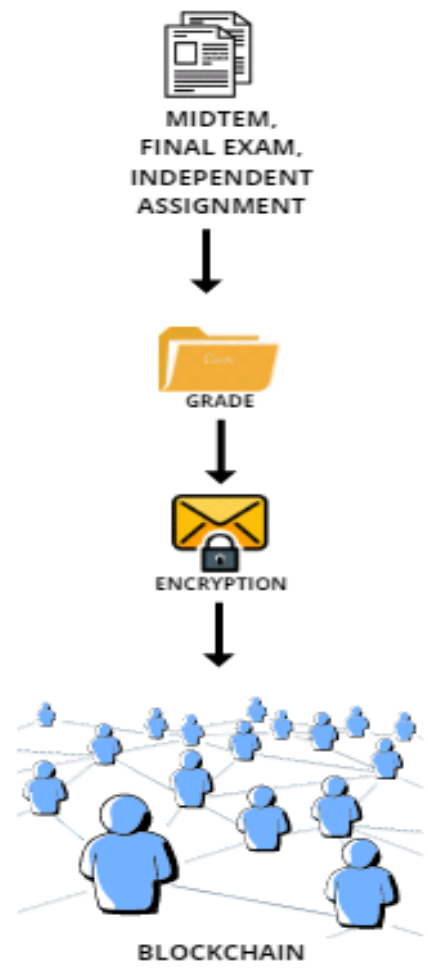

Figure 7. Blockchain implementation scheme in iLearning education

Figure 7 can know that the value consists of a midterm exam, a final exam, and an independent task. The amount would store in a system that integrates with the Blockchain. In terms of storage, Blockchain is assured of security level because every data recorded in the Blockchain will be converted into cryptography and distributed to each existing node, each node knowing what transaction between the nodes, By the Blockchain's decentralized nature and data transparency. In the Blockchain, third parties are no longer needed because the Blockchain is negating third parties and using peer to peer systems, so between the user and the receiver, no middlemen anymore. Thus, the Blockchain is said to be safe because of its decentralized system, transparency, and peer to peer.

\section{CONCLUSIONS}

Based on the problem outlined above, the problem can be solved using blockchain technology. With Blockchain technology, data security issues are resolved because the data that enters the Blockchain will pass the encryption process into random code and will not be the same. After that, the data distributed to all nodes or users on the Blockchain living environment. Every transaction or data exchange between users can be known to everyone, but other than the user concerned can not see the contents of the transaction.

The results of this study found that Blockchain technology can increase the security level of the ranking system. The value of data entered into the Blockchain will pass the encryption process into a unique code and will not be the same; after that, the data distributed to all nodes or users in the Blockchain environment. Each node that is connected will communicate with each other to match data from existing values. In this study, all values entered into the system will be recorded in a digital ledger to determine what processes occur in the system, by using this method, expected to reduce data modification crimes by irresponsible parties. For further research, we recommend expanding the research topic so that it is not correct 
by security issues alone, such as making smart contracts to develop Blockchain for scientific publications on campus, so that the discussion becomes more and more detailed.

\section{ACKNOWLEDGEMENTS}

We would like to thank the Ministry of Research and Technology/National Agency for Research and Innovation (RISTEK-BRIN) for funding this research. Special thanks to Raharja University, especially to REC (Raharja Enrichment Center), as an organization that has provided a friendly forum and lecturer staff and advisors to help complete this research.

\section{REFERENCES}

[1] Ś. Ž. Z Śăž and Z Ŷ Žz, "A High Performance Blockchain Platform for Intelligent Devices," 2018 1st IEEE Int. Conf. Hot Information-Centric Netw., no. HotICN, pp. 260-261, 2018, doi: 10.1109/HOTICN.2018.8606017.

[2] L. Stoykov, K. Zhang, and H. A. Jacobsen, "Demo: VIBES: Fast blockchain simulations for large-scale peer-to-peer networks," Middlew. 2017 - Proc. 2017 Middlew. Posters Demos 2017 Proc. Posters Demos Sess. 18th Int. Middlew. Conf., pp. 19-20, 2017, doi: 10.1145/3155016.3155020.

[3] P. File et al., "PENGAMANAN FILE SUARA MENGGUNAKAN," pp. 431-441, 1967.

[4] Z. Z. Deskiva, P. Studi, T. Informatika, C. Digital, P. Password, and P. Aplikasi, "IMPLEMENTASI KRIPTOGRAFI MODERN DENGAN METODE," pp. 44-49, 2014.

[5] N. Mohamed and J. Al-jaroodi, "Applying Blockchain in Industry 4 . 0 Applications," 2019 IEEE 9th Annu. Comput. Commun. Work. Conf., pp. 852-858, doi: 10.1109/CCWC.2019.8666558.

[6] A. Mushtaq and I. U. Haq, "Implications of blockchain in industry 4.O," 2019 Int. Conf. Eng. Emerg. Technol. ICEET 2019, 2019, doi: 10.1109/CEET1.2019.8711819.

[7] M. T. Budiyono, "Implementasi Blockchain dalam Sistem Layanan Kesehatan Sebuah Kajian Regulasi," 2018.

[8] X. Zheng, R. R. Mukkamala, R. Vatrapu, and J. Ordieres-mer, "Blockchain-based Personal Health Data Sharing System Using Cloud Storage," 2018, doi: 10.1109/HealthCom.2018.8531125.

[9] S. Wang, D. A. N. Zhang, and Y. Zhang, "Blockchain-based personal health records sharing scheme with data integrity verifiable," IEEE Access, vol. PP, p. 1, 2019, doi: 10.1109/ACCESS.2019.2931531.

[10] U. Rahardja, I. Handayani, N. Lutfiani, and F. P. Oganda, "An Interactive Content Media on Information System iLearning+," IJCCS (Indonesian J. Comput. Cybern. Syst., vol. 14, no. 1, p. 57, 2020, doi: 10.22146/ijccs.51157.

[11] J. Cheng, N. Lee, C. Chi, and Y. Chen, "Blockchain and Smart Contract for Digital Certificate," 2018 IEEE Int. Conf. Appl. Syst. Invent., pp. 1046-1051, 2018.

[12] V. Juričić, M. Radošević, and E. Fuzul, "Creating student's profile using blockchain technology," 2019 42nd Int. Conv. Inf. Commun. Technol. Electron. Microelectron., pp. 521-525, 2019.

[13] U. Rahardja, N. Lutfiani, I. Handayani, and F. M. Suryaman, "Motivasi Belajar Mahasiswa Terhadap Metode Pembelajaran Online iLearning + Pada Perguruan Tinggi Student Learning Motivation Against iLearning + Online Learning Method in Higher Education," pp. 192-202, 1978.

[14] U. Rahardja, N. Lutfiani, A. D. Lestari, and E. B. P. Manurung, "Inovasi Perguruan Tinggi Raharja Dalam Era Disruptif Menggunakan Metodologi iLearning," vol. 13, no. 
1, pp. 23-34, 2019.

[15] E. Nikbakht, M. Shahrokhi, A. Corriette, and A. Corriette, "Blockchain \& distributed financial data," 2019, doi: 10.1108/MF-10-2018-0470.

[16] L. Neumann, U. Dapp, W. Jacobsen, F. van Lenthe, and W. von Renteln-Kruse, "The MINDMAP project: mental well-being in urban environments: Design and first results of a survey on healthcare planning policies, strategies and programmes that address mental health promotion and mental disorder prevention for older people in Europe," $Z$.

Gerontol. Geriatr., vol. 50, no. 7, pp. 588-602, 2017, doi: 10.1007/s00391-017-1290-7.

[17] B. Siber, "DESAIN e-TRANSKRIP DENGAN TEKNOLOGI BLOCKCHAIN," pp. 16, 2019.

[18] U. Rahardja, N. Lutfiani, E. P. Harahap, and L. Wijayanti, "iLearning: Metode Pembelajaran Inovatif di Era Education 4.0,” Technomedia J., vol. 4, no. 2, pp. 261-276, 2019, doi: 10.33050/tmj.v4i2.1010..

[19] P. Studi, T. Informatika, F. T. Informasi, and U. Stikubank, "IMPLEMENTASI SEDERHANA BLOCKCHAIN," pp. 306-309, 2018.

[20] P. Urien, "Blockchain IoT ( BIoT ): A New Direction for Solving Internet of Things Security and Trust Issues . Invited Talk," 2018 3rd Cloudification Internet Things, pp. 14.

[21] W. Zheng, Z. Zheng, X. Chen, K. Dai, P. Li, and R. Chen, "NutBaaS : A Blockchain-asa-Service Platform," IEEE Access, vol. PP, p. 1, 2019, doi: 10.1109/ACCESS.2019.2941905.

[22] M. M. Queiroz, R. Telles, S. H. Bonilla, and R. Telles, "Blockchain and supply chain management integration : a systematic review of the literature," 2019, doi: 10.1108/SCM-03-2018-0143.

[23] M. Turkanović, M. Hölbl, and K. Košič, "EduCTX : A Blockchain-Based Higher Education Credit Platform," vol. 6, 2018, doi: 10.1109/ACCESS.2018.2789929.

[24] A. A. Maksutov, M. S. Alexeev, N. O. Fedorova, and D. A. Andreev, "Detection of Blockchain Transactions Used in Blockchain Mixer of Coin Join Type," 2019 IEEE

Conf. Russ. Young Res. Electr. Electron. Eng., pp. 274-277, 2019.

[25] H. F. Putra, W. Wirawan, and O. Penangsang, "Penerapan Blockchain dan Kriptografi untuk Keamanan Data pada Jaringan Smart Grid,” J. Tek. ITS, vol. 8, no. 1, 2019, doi: 10.12962/j23373539.v8i1.38525.

[26] S. Kamrat, N. Suesangiamsakul, and R. Marukatat, "Technical analysis for cryptocurrency trading on mobile phones," 2018 3rd Technol. Innov. Manag. Eng. Sci. Int. Conf., no. August, pp. 1-4, 2018, doi: 10.1109/TIMES-iCON.2018.8621823. 